\title{
"Why, you can be a journalist, kid": The Emerald Goose and Women's Journalism at Iowa State College during World War I
}

\author{
JENNY BARKER-DEVINE
}

ON APRIL 11, 1918, an article in the Iowa State Student lamented the absence of the Green Gander, the campus humor magazine published annually at Iowa State College (ISC, now Iowa State University) by the men of Sigma Delta Chi, a men's journalism society. It had been more than a year since the United States entered World War I and many college men left campus for military service or lucrative jobs in war industries. All was not lost, however. The Iowa State Student happily reported that the women of Theta Sigma Phi, a new women's journalism society, would release their own "scandal sheet" titled the Emerald Goose. An editorial in the first issue, published April 12, 1918, assured readers that this was merely a temporary wartime measure. "The Emerald Goose can not build ships, nor move freight, nor 'go over the top' with the boys. But we hope it can dispel gloom. We hope it can help keep cheerful the men who go- and the men and women who stay. This is our bit in this war." 1

The author would like to thank the anonymous reviewers whose advice much improved this article and Becky Jordan, Reference Specialist at the Iowa State University Archives, for providing the images and for digging deep into the records to provide crucial evidence regarding the demise of the Emerald Goose.

1. "Scandal Eggs Burst with Emerald Goose," Iowa State Student, 4/11/1918; “Nothing But the Truth," Emerald Goose, 4/12/1918, 8.

THE ANNALS OF IOWA 75 (Fall 2016). (C) State Historical Society of Iowa, 2016. 
In print, members of Theta Sigma Phi claimed patriotism as their primary motivation, adhering to wartime rhetoric that permitted women to take on masculine roles only for the duration. On the surface, the four issues of the Emerald Goose published between 1918 and 1921 support popular conceptions of women in wartime as a reserve labor force. Yet, with the support of faculty and a national network of female journalists, the women of Theta Sigma Phi harbored grander ambitions. They intentionally created their magazine as a platform to write for general audiences, draw attention to women's issues, and protest the scant opportunities for women in journalism on campus and in the professional world. Furthermore, a contextual analysis of the Emerald Goose lends insight into how the upheavals of wartime and the 1918 flu epidemic affected gendered dynamics and generational conflict on a midwestern college campus.

The Emerald Goose, a seemingly small footnote to history, provides lessons on commemoration as we approach the centennial of U.S. involvement in World War I. Celebratory reflections will certainly use sources like the Emerald Goose to demonstrate how the conflict paved the way for woman suffrage and greater economic equality. For more than three decades, historians of American women have countered such notions by focusing on World War I as a focal point within the context of broader social, cultural, and political changes that unfolded over the course of several decades. Historian Barbara Steinson observes that World War I "created a climate for the continuing role of women on the public stage." Similarly, historian Maurine Weiner Greenwald argues that wartime demands brought to a head issues generated by the steady increase of women in the workforce that began in the 1870s. Labor shortages during the war allowed workers to "move from a defensive to offensive position" and to engage in strikes and smaller-scale labor revolts. In other words, experienced female workers and activists behaved intentionally, building on past experiences to bank on wartime rhetoric and move incrementally toward lasting change. ${ }^{2}$ The Emerald Goose, then, was the product of protest, as women contested for space in the

2. Barbara J. Steinson, American Women's Activism in World War I (New York, 1982), 400; Maurine Weiner Greenwald, Women, War, and Work: The Impact of World War I on Women Workers in the United States (Westport, CT, 1980), 38-39. 
student newsrooms at Iowa State College and asserted their right to participate in curricular and extracurricular journalism.

IN THE EARLY TWENTIETH CENTURY, professional newsrooms were male domains. Many male editors deemed the seedy beat of the average reporter inappropriate for the "gentle sex" and claimed that women lacked the stamina and skills to undertake serious writing. In 1898 editor E. A. Bennett asserted, "Women enjoy a reputation for slipshod style. They have earned it. . . . Not more than ten percent of them can be relied upon to satisfy even the most ordinary tests in spelling, grammar, and punctuation." In 1903, in what is considered the first journalism textbook, author Edwin L. Schulman warned women to avoid taking "chances with the men." He concluded that reporting robs a woman of her "feminine characteristics" and "rubs the bloom off a woman much more quickly than teaching or employment in a business office." Editors sometimes employed so-called "sob sisters" to write sensational, emotive stories about tragic events, or for harrowing undercover assignments in slums and prisons, but their work was more often the object of ridicule. The majority of women in journalism wrote society columns, literature and film reviews, or material for designated "women's pages" on fashion, recipes, homemaking, and childrearing. Such work could be done freelance from the confines of home for significantly less compensation than that of a full-time reporter. ${ }^{3}$

At the time, journalism was a novel subject of study at the collegiate level, and student newsrooms had yet to be entirely demarked along gendered lines. The University of Missouri-

3. E. A. Bennett, Journalism for Women: A Practical Guide (London and New York, 1898), 15-16; Genevieve G. McBride and Stephen R. Byers, "On the Front Page in the 'Jazz Age': Journalist Ione Quinby, Chicago's Ageless 'Girl Reporter,', Journal of the Illinois State Historical Society 106 (2013), 93-94; Edwin L. Shuman, Practical Journalism: A Complete Manual for the Best Newspaper Methods (New York, 1903), 150, quoted in Jean Marie Lutes, Front Page Girls: Women's Journalists in American Culture and Fiction, 1880-1930 (Ithaca, NY, 2006), 9; Matthew Goodman, Eighty Days: Nellie Bly and Elizabeth Bisland's History-Making Race Around the World (New York, 2014), 8-12; Alice Fahs, Out on Assignment: Newspaper Women and the Making of Modern Public Space (Chapel Hill, NC, 2011), 2-9, 13-15; Linda Steiner, "Gender at Work," Journalism History 23 (1997), 2-13; Amber Roessner, "'The Great Wrong': Jennie June's Stance on Women's Rights," Journalism History 38 (2012), 182. 
Columbia (MU) was the first to establish a school of journalism in 1908, leading the way in the field. ISC did not offer a journalism major until 1925, but beginning in 1905 students could take courses in journalistic writing as it related to home economics, agriculture, engineering, and forestry.

In 1909 male students at DePauw University founded Sigma Delta Chi as the nation's first journalism society, but they intentionally excluded women. That same year, female students at the University of Washington (UW), which housed the second school of journalism founded in the United States, established Theta Sigma Phi upon the advice of faculty. By 1915, the organization had chapters at the universities of Wisconsin, Kansas, Indiana, Ohio, Oklahoma, and Oregon. In March 1917, more than a year before the initial publication of the Emerald Goose, a group of women at Iowa State College sought a charter from Theta Sigma Phi with the clear intention of promoting women's journalism at ISC. All of the applicants had prior experience in writing and editing and stated in their petition for national membership that they aspired to professional careers in journalism. ${ }^{4}$

On January 11, 1918, seven women at ISC formally established the Omicron chapter of Theta Sigma Phi after nearly 18 months of planning. In doing so, they joined a larger movement to contest sexism by creating professional networks for women in journalism. The process of founding a chapter began with a serendipitous meeting between Merze Marvin, a 1916 graduate of MU, and Harry $\mathrm{O}^{\prime}$ Brien, a professor of journalism at ISC who oversaw all student publications. At the time, Marvin was employed in the advertising department of the Des Moines Register, and she understood fully how sexism had shaped her career. In 1916 Walter Williams, the dean of the MU School of Journalism, refused to recommend Marvin for a faculty position at UW. She was "especially well qualified," Williams wrote to UW journalism professor Frank Kane; "her sex is her only drawback." Kane replied that he held no personal prejudice against women but agreed that Marvin's sex would "limit her cruelly." This is especially bizarre given that the UW faculty had supported the for-

4. Victoria Goff, "Association for Women in Communications, 1909-Present," in Women's Press Organizations, 1881-1999, ed. Elizabeth V. Burt (Westport, CT, 2000), 11-13. 
mation of Theta Sigma Phi only seven years prior. Undeterred, Marvin became an outspoken advocate for women in journalism, with a special interest in enhancing collegiate programs. In a 1918 editorial for Theta Sigma Phi's national magazine, The Matrix, she accused colleges and universities of failing "in giving women their opportunity." Convinced by Marvin's tenacity, in the fall of 1916 O'Brien suggested to his female students that they form a chapter and enlist Marvin's help. ${ }^{5}$

$\mathrm{O}^{\prime}$ Brien was still early in his tenure at ISC. He had earned an M.A. in English from Ohio State University in 1912 and arrived at ISC in 1915 after building an agricultural journalism program at Oklahoma State University. It is surprising that he reached out to female students given curricular limitations that prevented women from even enrolling in most ISC journalism courses. During the 1917-18 academic year, ISC offered 11 courses in the field of technical journalism, including introductory classes on journalistic writing and editing, agricultural advertising, bulletin writing (for aspiring extension agents and researchers), rural newspaper management, and the management of technical journals. These courses prepared students to apply their agricultural and scientific knowledge as writers and editors for technical periodicals, and many students found employment with magazines such as Wisconsin Farmer, Wallaces' Farmer, Successful Farming, and Prairie Farmer. ${ }^{6}$

5. By 1910, more than two dozen women's press clubs operated in 17 states, facilitating a rapid increase in the number of female journalists so that by 1920 , 16 percent of all journalists were women. See Lutes, Front Page Girls, 8; Susan Henry, "'But Where Are All the Women?': Our History," in Seeking Equity for Women in Journalism and Mass Communication Education: A 30-Year Update, ed. Ramona Rush, Carol E. Oukrop, and Pamela J. Creedon (Mahwah, NJ, 2004), 3; Merze Marvin, "Why Not Women Instructors in Journalism?" The Matrix (May 1918), quoted in Goff, "Association for Women in Communications," 13; "Theta Sigma Phi at Iowa State" (1968), in Women in Communications, Inc. Records, MS 35, Iowa State University Archives, Parks Library, Iowa State University, Ames (hereafter cited as WIC Records).

6. Iowa State College of Agriculture and Mechanic Arts General Catalogue, 1917-1918 15, no. 32 (Ames, 1917), 107-10. ISC was coeducational from its founding, but in the 1910s, female students remained a minority. Exact enrollment numbers are not available for every year, but female enrollment experienced a rapid increase from only 360 in 1912 to 1,500 in 1927. It is also possible to estimate from the number of students enrolled in each major. In 1914-15, 72 percent of the 2,974 ISC students majored in the male-dominated subjects of agriculture, engineering, and veterinary medicine, while 28 percent majored in areas dominated by 
The 1917-18 ISC catalog clearly delineated journalism courses along gendered lines with a bold heading: "Journalism for Women." Only three of the eleven available journalism courses were offered for women: Beginning Technical Journalism, Technical Journalism Practice, and Management of a Technical Journal. Furthermore, female students had little time to take these electives. The 1918-19 catalog outlined programs of study for home economics majors that provided few opportunities to choose general electives. Students specializing in household arts (which emphasized textiles, clothing, and art history) or household science (which emphasized nutrition and hygiene) were allowed to take only $1 \frac{1}{3}$ elective credits during their junior year, and between three and six elective credits during their senior year. That number was further reduced by the requirement that students choose their electives from a limited set list. The course Beginning Agricultural Journalism appeared among the available electives but not until the fourth year of study. Students majoring in home economics could also specialize in agriculture to prepare them for farm management, extension work, or agricultural education at the high school level, but the program of study offered no courses in journalism nor any room for free electives. In contrast, male students majoring in civil engineering were allowed ten elective credits during their junior and senior years, while male students majoring in agronomy were required to take Beginning Agricultural Journalism and were allowed 15 elective credits during their junior and senior years. Those majors clearly allowed male students greater flexibility in shaping their education. ${ }^{7}$

females: home economics, industrial science, and music. Even by 1917-18, at the height of American involvement in the war, little had changed; 67 percent of 2,700 students majored in agriculture, engineering, and veterinary medicine, while 33 percent majored in home economics, industrial science, and music. Even during wartime, women did not experience large gains in numbers and did not encounter increased opportunities to participate in student activities or student leadership positions. See "Iowa State College Summary of Attendance," Report of the Iowa State Board of Education for the Biennial Period Ending June 30, 1920 (Des Moines, 1920), 145. The women of Theta Sigma Phi estimated that approximately 600 women were enrolled at ISC. "Petition to Theta Sigma Phi," in Theta Sigma Phi Records, RS 22/05, Iowa State University Archives, Parks Library, Iowa State University, Ames (hereafter cited as Theta Sigma Phi Records).

7. Clarence M. Baker, "State Men in Agricultural Journalism," The Ohio State University Monthly 9, no. 6 (March 1918), 31; "Petition to Theta Sigma Phi," in 
College policies further inhibited women's participation in journalism by limiting their extracurricular activities. In 1914 ISC administrators devised a point system that gave value to specific activities in order to avoid situations in which "one man or woman is elected or appointed to many positions because of unusual popularity." They assigned each activity a specific point value and prohibited students from accumulating more than 50 points. For example, the president of the Cardinal Guild (the student government organization) earned 20 points, while the editor of the student newspaper earned 35 points. Activities that required less time, such as working as a reporter for the student newspaper, earned just 10 points. ${ }^{8}$

ISC administrators developed very different plans for men and women. Activities listed as appropriate for men included nearly all high-status positions, such as president of the Cardinal Guild, class officers, varsity athletics, and all leadership positions on major campus publications. In contrast, the list for women featured major leadership positions within just three women's organizations: the Home Economics Club, the Forensics League, and the YWCA. The system further devalued women's participation by assigning them higher point values. For example, the presidency of the YWCA was worth 35 points, as compared to 25 points for the president of the YMCA. ${ }^{9}$

With these curricular and extracurricular restrictions, few women participated in extracurricular journalism. By the 1910s, ISC offered six different student publications: the Iowa State Student, the Bomb (the yearbook), the Iowa Engineer (established in 1901), the Iowa Agriculturalist (1902), the Ames Forester (1913), and the Green Gander (1915). The Iowa Agriculturalist included women's pages written and edited by female students, but ISC did not sponsor a periodical devoted specifically to women until the Iowa Homemaker commenced in 1921. Women did not enjoy equal opportunities to work on these publications. In 1918 the 27-member

Theta Sigma Phi Records; Iowa State College of Agriculture and Mechanic Arts General Catalogue, 1918-1919 16, no. 44 (Ames, 1919), 216-28; Iowa State College of Agriculture and Mechanic Arts General Catalogue, 1917-1918 15, no. 32 (Ames, 1917), 167-73, 208-11.

8. "The Point System," in When Freshmen Come to ISC (Ames, 1915), 12-16.

9. Ibid. 
Bomb staff included just three women. The 39-member staff of the Iowa State Student also included just three women: the social editor and two reporters. Three women, out of a staff of 20, worked on the home economics section of the Iowa Agriculturalist, and none worked for either the Iowa Engineer or the Ames Forester. ${ }^{10}$

As they contemplated their petition to Theta Sigma Phi, the women at ISC understood that forming this new group would require them to devote nearly all of their extracurricular points to journalism, especially if they wanted to take on leadership roles. Electing not to mention these limitations, they instead painted a more optimistic picture. The petition emphasized that six of the seven prospective members had already earned credits in journalism courses, though none had enrolled in those outside of the courses listed under the heading Journalism for Women. ${ }^{11}$

The petition promised growth by noting that during the 1915-16 academic year 57 women had enrolled in one or more journalism courses; during the 1916-17 academic year, the number grew to 77 . The petitioners believed that their technical training from courses in home economics and the sciences, combined with journalistic instruction, qualified them for jobs in home and family departments in agricultural publications and at women's magazines. They presented ample evidence to support their claims. After 1915, women from ISC won writing contests sponsored by the Ladies' Home Journal, and many worked as freelance contributors to magazines such as Woman's Home Companion, McCall's, Successful Farming, Farm and Fireside, and The Fruit Grower. Furthermore, they found inspiration from alumni such as Louise Peck ('13), the household editor of the People's Popular Monthly in Des Moines, and Clara Steen ('14) and Tura Hawk ('16), who did "considerable feature writing for the big magazines." 12

All of the applicants boasted impressive resumés. Founding member Norma Daniels, a junior chemistry major, worked as a reporter for her hometown newspaper, the Eldon Forum, and on

10. Bomb (1918), 170-77. These numbers were similar to those in 1917, when 9 women worked on the Bomb (out of a total staff of 32), 2 women worked on the Iowa State Student (out of 29), 3 worked on the Iowa Agriculturalist (out of 23), and none worked on either the Iowa Engineer or the Green Gander. Bomb (1917), 374-80.

11. "Petition to Theta Sigma Phi," in Theta Sigma Phi Records.

12. Ibid. 
the home economics sections of the Iowa Agriculturalist. Phoebe Mentzer, a junior in home economics, worked for the Iowa State Student and contributed feature articles to Ladies' Home Journal and the Des Moines Register. Gladys M. Hultz, a senior in home economics, worked on the Bomb, served for two years as society editor for the Iowa State Student, and, like other founding members, worked on a sorority newsletter. They all intended to pursue professional careers in journalism following graduation. They believed that their experiences revealed a "developing widespread interest in journalistic study among the women at Iowa State College," and they hoped that interest would continue to grow. ${ }^{13}$

On March 22, 1917, just a few weeks before the United States went to war, the women students finally submitted their petition to the national chapter of Theta Sigma Phi. They wrote nothing about promoting women's journalism only for the duration of the war or about filling leadership positions left absent by men; rather, they wished to "seriously devote" themselves to advancing women's journalism at ISC. ${ }^{14}$

When national Theta Sigma Phi president Helen Ross Lantz charged Merze Mervin with the Omicron chapter's installation ceremony in January 1918, she affirmed that the women at ISC should maintain that devotion. Marvin was to impress upon the new members that "as an organization they must mean something. Warn them against having too many parties and teas. In the main their meeting should be for the purpose of discussing professional matters." Lantz, Marvin, and the members of Omicron chapter understood that they were part of a broad national network that relied on strength in numbers. ${ }^{15}$

THE CHAPTER'S ACTIVITIES happened to coincide with the development of a home-front rhetoric that authorized authority figures to accept women's public engagement. On April 19, 1917, just two weeks after Congress declared war, ISC administrators adopted wartime programs for female students. Catherine McKay, dean of home economics, outlined a program of women's war

13. Ibid.

14. Ibid.

15. Helen Ross Lantz to Merze Marvin, 1/8/1918, Theta Sigma Phi Records. 
work with courses on hygiene and home care of the sick, voluntary work, hospital supplies, knitting and sewing, emergency building, drying and preserving vegetables, gardening, stock feeding, beekeeping, and poultry raising. Although women also participated in fund drives, the sale of Liberty Bonds, and customary female activities sponsored by the Red Cross and the YWCA, college administrators focused on impending labor shortages. They offered courses in agriculture and technical subjects, including a women's "tractor school." On May 17, 1918, Robert E. Buchanan, then dean of industrial sciences, insisted that ISC administrators increase women's enrollment and train them for the growing number of professional and scientific positions across the country. The efficient instruction of young women was, after all, a "patriotic duty" so long as the country was at war. ${ }^{16}$

It was within this context that the members of Theta Sigma Phi minimized their professional ambitions and emphasized wartime rhetoric. On May 7, 1918, shortly after the debut of the Emerald Goose, an editorial in the Iowa State Student titled "Women in Journalism" fully supported women's temporary employment in journalism as a means to fulfill their patriotic duties. Signed only "J. W.," it was likely authored by Josephine Wiley, an early initiate of Omicron chapter. She wrote, "With our men constantly pledging themselves in the national service, we believe it to be the patriotic duty of the women who are entering professions at this time, be they newspaper or otherwise, should also pledge for a definite period of time." The editorial noted that homemakers could remain within their home while using their skills to publish useful articles on "war time recipes and suggestions on furnishing a dining room in blue and white." Taking it one step further, Wiley then asserted that women were capable of much more than writing articles concerning society and the home; women reporters could easily write two columns on the fire across town and the "pro-German who started it." The editorial clearly framed women's work as temporary and unusual. ${ }^{17}$

16. “Assignments Made for Women's Work," Iowa State Student, 4/19/1917; "Tractor School for Girls Now Possible," Iowa State Student, 5/10/1917; Earle D. Ross, A History of Iowa State College of Agriculture and Mechanic Arts (Ames, 1942), 304-5; Iowa State Student, 5/17/1918.

17. “Women in Journalism," Iowa State Student, 5/7/1918. 
At first glance, the women of Theta Sigma Phi appear to have acted in accordance with college policy and served as members of a reserve labor force, reluctantly taking the place of men for the duration of the war. In April 1918 they dedicated the first issue of the Emerald Goose to the absent men of Sigma Delta Chi and asserted, "When the Green Gander went to war the [Emerald Goose] stepped in his place." In the second issue, published in March 1919, the women again downplayed their efforts. The editors wrote that as a result of the war, the Emerald Goose filled the "vacancy in the hearts of Iowa State College people." Using the titles of their publications as representative characters, the women described how, once the Green Gander returned "with victoriously beating wings," the Emerald Goose anxiously "waddled forth to greet him." 18

BY PORTRAYING the Emerald Goose as a wartime measure, its creators minimized its significance. A century later, the same rhetoric often prevents us from appreciating its value as a historical source. It would be easy to dismiss the magazine as a mere replacement of the Green Gander, but a closer examination reveals how members of Theta Sigma Phi used humor to reflect on women's collegiate experiences.

Historian Beth Bailey discerned that campus publications provided important information regarding proper middle-class manners, behavior, and attitudes toward consumer items. The growth of magazines around the turn of the century shaped a "remarkably coherent universe" of convention not only on local campuses, but for nearly all college students across the country. That code of conduct proved necessary as more young people attended college and interacted with the opposite sex without the guidance of watchful parents. Yet because most college publications were produced by men, material for women was often prescriptive or written in condescending, dismissive tones. ${ }^{19}$

That was certainly true for the Green Gander. Excluding women from Sigma Delta Chi also excluded them from writing

18. "Nothing But the Truth," Emerald Goose, 4/12/1918, 8; "Beta Number," Emerald Goose, 3/19/1919, 8.

19. Beth L. Bailey, From Front Porch to Back Seat: Courtship in Twentieth-Century America (Baltimore, 1989), 8-9, 14-15. 
for the organization's magazine. As a result, the Emerald Goose provided a rare platform for women's authentic voices.

Both ISC humor magazines - the Green Gander, first published in 1915, and the Emerald Goose, first published in 1918 - gave students an opportunity to promote campus unity by looking at the lighter side of student life. In the first issue of the Green Gander, one contributor noted the necessity of humor at a college dedicated to two very serious and somewhat somber vocations: agriculture and housekeeping. He wrote, "If the editors of the Green Gander can by increasing the amount of joy, foolishness, humor, lightness of outlook, and cheerfulness of disposition in these two mighty professions, they will rank with the benefactors of the ages." 20

Student writers and editors poked fun at themselves, the faculty, administrators, and the rules by which students were to abide. In many ways, the writers and editors attempted to level social relationships by consistently remarking that no foolish act, even those of professors and deans, was safe from exposure. Yet the experience could be quite different for men and women. Literary scholar Catherine Keyser asserts that in the 1910s and 1920s, humor was especially important for female writers because it "facilitates self-invention and cultural commentary." The Emerald Goose was more than a forum for poking fun. It allowed women to critique the administration's strict limitations on their behavior and the largely unregulated lives of male students, all the while diffusing tensions over appropriate gender roles. Over the course of four years and four issues, the Emerald Goose shows the complexity and limits of humor in challenging established gender norms. ${ }^{21}$

The two ISC magazines differed in how they promoted gendered social conventions and campus unity. Early issues of the Green Gander featured stories and jokes that reinforced a competitive, masculine culture on campus by emphasizing varsity athletics (primarily football), the draft and military service, hazing rituals, fraternities, and the joys of bachelorhood. These strengthened existing traditions that were often imbued with violence.

20. George Fitch, “When George Came Home,” Green Gander, 4/1/1915, 5.

21. Catherine Keyser, Playing Smart: New York Women Writers and Modern Magazine Culture (New Brunswick, NJ, 2010), 10. 


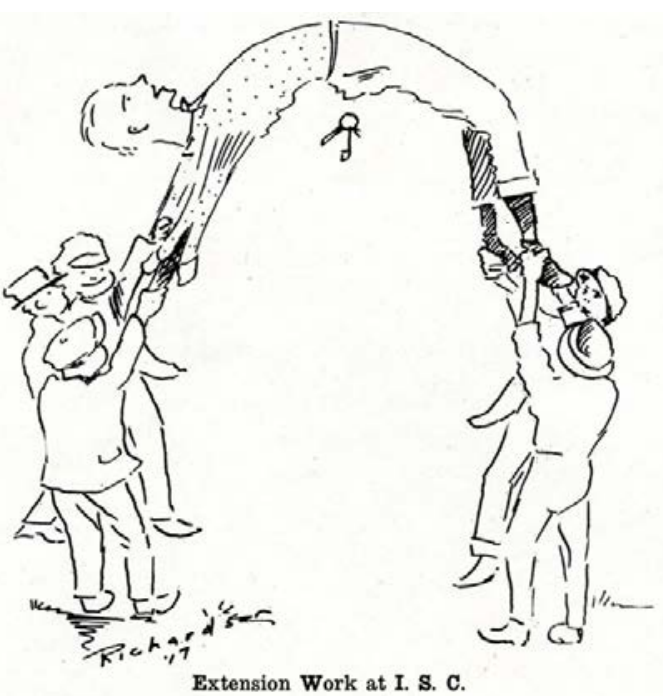

From The Green Gander, April 1915, 6. All images courtesy Special Collections and University Archives, Iowa State University.

A favorite topic was humiliating freshman initiation rituals. According to a 1915 freshman orientation manual, male first-year students were required to wear beanies from 8 a.m. to 6 p.m. every day (except Sunday) and were forbidden from wearing collegiate insignia or calling upperclassmen by their nicknames. In 1909 the Cardinal Guild outlawed physical hazing practices, including "stretching," whereby four upperclassmen picked up a freshman, one holding each limb, and shook him vigorously until all of the change fell out of the unfortunate freshman's pockets. Nonetheless, an illustration of the ritual, with the caption "Extension work at ISC," appeared in the first issue of the Green Gander, showing that the practice was still part of campus life in $1915 .{ }^{22}$

22. Green Gander, April 1915, 6. The practice of wearing beanies, or "class caps," was not simply a student ritual. It was endorsed by the administration. Strict guidelines dictated that all caps were to be maroon in color with buttons on the top to signify the freshman's major. At the end of each academic year, the freshmen held a bonfire at which they burned their caps and celebrated their promotion to sophomore status. When Freshmen Come to ISC, 22-23. 
References to dating and women in the Green Gander often included silly sketches denoting women's frivolity and the silliness of their beauty regimens, poking fun at the high cost of dating, and portraying marriage as a dreaded affair. The male writers' stories reveal that they expected to date widely and enjoy physical interaction with women without serious commitment. In a nod to female intelligence, they also noticed the exceptional nature of college-educated women. One 1917 issue featured a comment that no man married to an "Ames girl" could claim an exemption from the draft on the grounds of caring for "a dependent." The same issue featured a daring poem concerning the strange, somewhat unfeminine skills of Edith Curtiss ('18), an ISC student and the daughter of Charles F. Curtiss, dean of the Agriculture Division. The poem indicated that she could "judge horses, hogs and lowing kine," but because she could not cook, her father "at the cafeteria ... doth dine." 23

The editors of the Green Gander occasionally sympathized with female students by condemning the rules that governed women's conduct. Those rules were in keeping with guidelines at similar institutions throughout the United States, although the disparity in gendered expectations at ISC may have been intensified by the absence of male dorms. Men enjoyed a significant degree of personal freedom because they chose to live in boardinghouses, stay with families, or join fraternities. Women, by contrast, were required to live in dormitories overseen by housemothers who enforced strict rules handed down by the "advisor to women." Female students were to study between 8 p.m. and 10:30 p.m. Monday through Thursday and have their lights out at exactly 10:30 p.m. They were allowed "eight light cuts" per person per quarter so long as they did not occur on two consecutive nights. Women adhered to a 10 p.m. curfew on Friday nights, with lights out by 11 p.m., and a midnight curfew on Saturdays. Women's activities on and off campus were strictly monitored. They could not attend a dance if it did not have a college sanction (and prior to 1920 college-sanctioned dances only occurred on Saturday nights), daytime picnics were to end before dusk, all evening picnics required chaperones, and if a woman expected to 
return to the dorm after 6 p.m., or if she planned to leave Ames for any reason, she needed to inform her housemother. ${ }^{24}$

Articles in the Green Gander occasionally addressed such rules. In April 1917 one article spoke out against the installation of electric lights "in every cozy retreat" on campus. The lights imposed on couples' privacy and, thereby, their ability to "mate." The writer of the article wondered why, "in the age of eugenics and science," administrators would "work so hard to prevent bright, young college students from falling in love." Later that year, an article in the homecoming issue scoffed at the strict rules posted in sorority houses that governed the women's behavior. The writer asked, "Are the girls of Iowa State less able to take care of their own thoughts and actions than the men? Such fossilized remains of antiquated ideas as are exhibited by the Women's By-Laws might well have been relegated to the ash heap years ago." 25

The first issue of the Emerald Goose, released in April 1918, mirrored the format of the Green Gander, consisting primarily of short poems, jokes, cartoons, and a few short, short stories. The writers were not quite as daring as those in the Green Gander. The jokes were aimed primarily at fellow students, administrators, and faculty, but more often they used pseudonyms and cryptic language that required firsthand knowledge of individuals' antics. Nevertheless, the writers expressed desires for greater personal freedoms. One poem described library dates, where couples met in the dark stacks. Rather than describe this as an exciting, positive venture, though, the poet expressed annoyance at not being able to study on account of all the noise. A short story titled "For Freshman Girls" featured the misadventures of two young women who missed curfew by two minutes. After trying to pry open the doors of the women's dormitory, they were caught by an angry housemother in "kid curlers" who let them in without consequence. Rather than directly challenging the rules, the moral of the story was simply to "tell the chaperone so she will be there

24. Mark Walter Robins, "American Anxiety and the Reaction of Michigan Agricultural College," American Educational History Journal 31 (2004), 73; Official Rules Concerning Student Conduct, with Suggestions in Regard to Health and Mental Hygiene (Ames, 1924), 14-16.

25. "Making It Harder to 'Fuss,' " Green Gander, 4/1/1917, 4; “Girls, You Should Appreciate Such Motherly Interest," Green Gander, 11/10/1917, 8. 
to greet you." Overall, the first issue of the Emerald Goose reflects a hesitation on the part of female students to cross boundaries of propriety, a hesitation that the writers of the Green Gander did not share. The following year, however, the women of Theta Sigma Phi produced a very different magazine. ${ }^{26}$

The 1918-19 academic year was one of upheaval at ISC. In February 1918 the campus welcomed a contingent of 500 recruits with the Student Army Training Corps (SATC), a nationwide military program that provided eight weeks of technical instruction. In the fall of 1918 an even larger group of 1,200 men arrived for a more elaborate SATC program that combined academic studies with technical training. By October, however, the Spanish influenza epidemic derailed all campus activities. At its height, more than 1,250 cases were reported primarily among the SATC, and 52 SATC cadets died as a result. As State Gym and a nearby church were converted into makeshift hospitals, administrators enforced a strict quarantine to keep the disease out of the women's dormitories and the larger Ames community. The responsibility for keeping female students healthy fell to Fredrica Shattuck, an instructor of speech and theater, who reluctantly took over as the Acting Advisor to Women on October 1, 1918, when her predecessor became ill. ${ }^{27}$

The epidemic eased by early November 1918 and the administration's efforts to contain it proved successful, but the disease and the quarantine remained on campus through January and February 1919. The second issue of the Emerald Goose, published in March 1919, expressed women's restless resentment of the quarantine rules that tightened their already strict regulations. The very first page took a jab at the Acting Advisor to Women in a cartoon of female students brainstorming ideas in O'Brien's office stating, "But Mr. O’Brien we can't, Miss Shattuck won't let us." Even more revealing is a cartoon featured prominently on the second page. Four young women play strip poker while a shocked Shattuck peers through the door. A poem, written as a

26. "Ye Campus Gossip" and "For Freshman Girls," Emerald Goose, 4/12/ 1918, 10, 22.

27. Becky Jordan, “1919: A Glimpse of Campus Life 70 Years Ago,” Exhibit Catalog 42 (1989), Iowa State University Archives, Parks Library, Iowa State University, Ames, 1-2. 


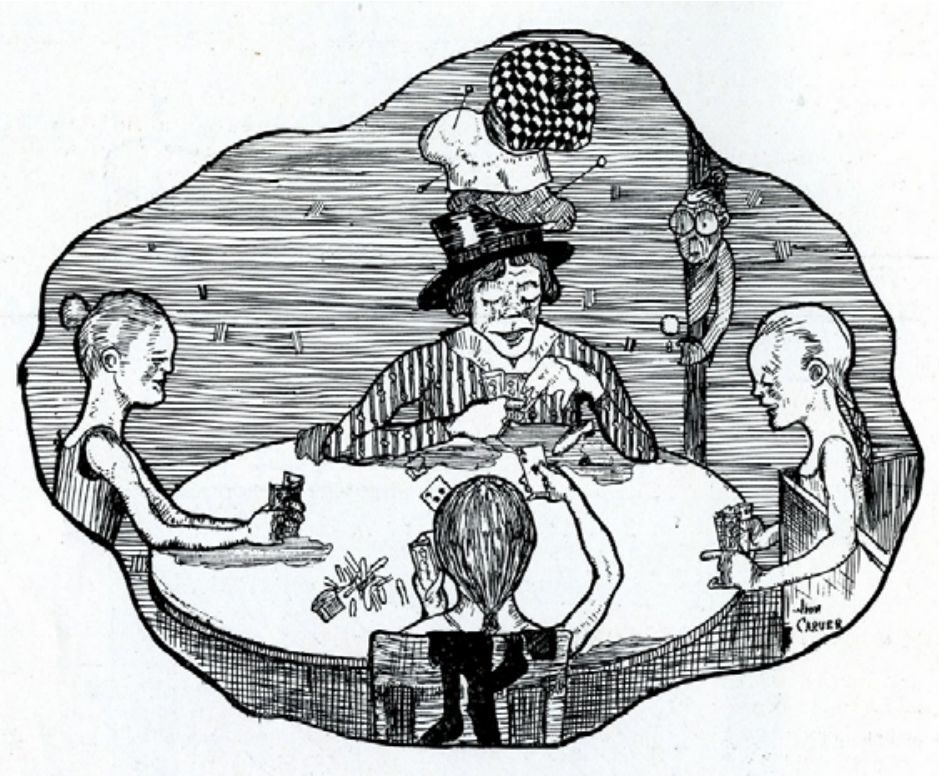

From The Emerald Goose, 3/19/1919.

letter from a female student to her brother stationed in France, described how the women were "bored to tears" because of the quarantine. They believed the game to be innocent, but after being caught, the poem's subject says she has been expelled, explaining sarcastically, "We're court martialed/And reduced in rank. / We are shameful/And immodest/And unlady-like/And a menace/To the morals / Of the institution, / And a discredit / To the ideals / Of I.S.C." The cartoon and the poem were based on actual events, when six female students living in Lyon Hall were suspended for the remainder of the quarter. The cartoon and poem, then, were not exaggerated musings on female sexuality but rather public expressions of protest and solidarity with the suspended students. ${ }^{28}$

That was only the beginning. The entire 1919 issue was peppered with poems and stories questioning double standards for men and women. One short story titled “Dorain Dewey's Di-

28. Untitled cartoons and poem, Emerald Goose, 3/19/1919, 3-4; Jordan, "1919," 3-4. Interestingly, the mother of one offender wrote to Shattuck, reproaching her for forcing the women to leave campus during the epidemic and for not providing more "amusements" to keep the women out of trouble. Jordan, "1919," 3-4. 
lemma-How will it be in Ames in 1975?" playfully predicted that in 1975 gender roles would be entirely reversed. By then it would be the young college men whose lives were strictly regulated to preserve their sexual purity. When the main character, Dorain Dewey, steps off the train in Ames, he wonders if he should plan on a career or simply "win his way upward, perhaps into the heart of some strong, manly millionaires." His dreams are dashed as he is thwarted by unfriendly policewomen, "husky cabwomen," and a scheming seductress. His only salvation is a fine, upstanding woman who proposes at the end of the story and allays Dewey's fears of personal failure. The story itself provides a sharp critique of double standards for women and their daily struggles with harassment and personal safety. Telling the story in a humorous light allowed it to appeal to a general audience and raise significant issues without fully challenging male authority. Similar concerns emerged from a poem in the same issue titled "The Eternal Question."
Johnny may go to the dances,
Oh, Johnny may go to the fair,
And Johnny may go where he pleases,
Now, really, do you think that quite fair?
And why may I not do as Johnny?
Or why does not Johnny do as me?
And why may I not do as Johnny
As well as another body?

The final emphasis on one's "body" in the poem is especially revealing when one considers how laws at the time regarding rape and sexual violence typically held "a woman's behavior as the standard defining whether rape occurred." Historian Kimberly Jensen finds that concerns about violence, whether it was domestic violence, sexual assault, rape, murder, or a hostile workplace, had a "profound effect" on the strategies women developed when entering public spaces. "The Eternal Question" laid bare a significant issue in the lives of college women living on a campus where they were far outnumbered by men. ${ }^{29}$

29. “Dorain Dewey's Dilemma-How will it be in Ames in 1975?" Emerald Goose, 3/19/1919, 9; "The Eternal Question," ibid., 21; Kimberly Jensen, Mobilizing Minerva: American Women in the First World War (Urbana, IL, 2008), 21-22. 


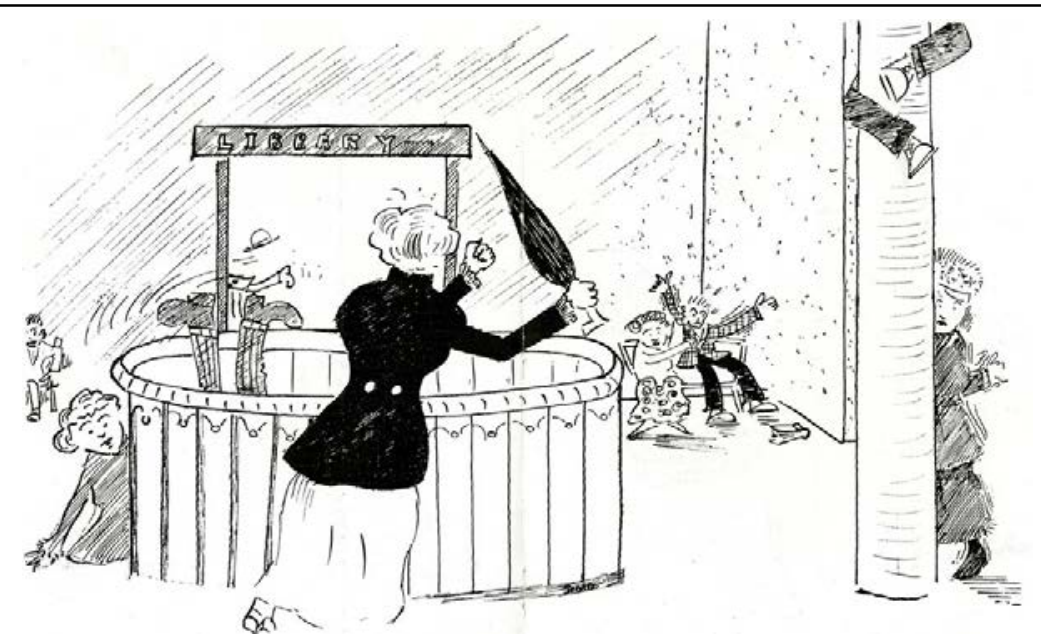

From The Emerald Goose, 3/19/1919.

Rather than setting themselves apart from the male students, the contributors to the 1919 issue used poems and cartoons to express women's sexual desires and their wish to partake in campus unrest alongside the men. As literary scholar Catherine Keyser pointed out, as much as a female writer might use humor to mock others' behaviors, quite often "she also wants to participate in it." One poem titled "The Fussers Baedecker" suggested several dark spots on campus for "spooning" with one's lover. Just as in the 1918 issue, the 1919 issue again referenced library dates. This time, however, a cartoon spread across two pages illustrated the practice, undermining Shattuck's authority by portraying her thundering through the library wielding an umbrella as spry couples took cover. ${ }^{30}$

Throughout January and February 1919, rebellious students overwhelmed administrators occupied with enforcing the quarantine and overseeing demobilization of the SATC. The most notorious incident occurred on February 6, 1919, when members of the Beta Theta Pi fraternity butchered a hog on a farmer's property and took it back to the fraternity house. As it turned out, the hog was a prized boar belonging to Agriculture Dean Charles

30. Keyser, Playing Smart, 167; Emerald Goose, 3/19/1919, 16-17, 23. 
Curtiss. The incident was the subject of at least seven poems and one cartoon in the 1919 issue of the Emerald Goose that, for the most part, made light of the situation. For example, one small blurb read: "The Betas may be good thieves, but in porch climbing they still have something they can learn from Parley Sheldon and Bill Hawkins, who have long had practice at the gentle art on the fire escape of West Hall." This referenced an actual incident when male students climbed into the female dormitories through the windows to join an all-female dance. While the item chided the Betas, it identified and even complimented the men who made the ascent. ${ }^{31}$

The one exception, a poem titled "The Double Standard," drew attention to the fact that, even with the destruction of property and theft, the men who stole the prize boar received the same punishment as women caught breaking curfew.

I go to a show on a Tuesday nite,

Quite much against the college rule;

I am caught, I am tried, I am sentenced to pay,

But, by jinks, I'll be hanged if it's fair.

My Friend, Mr. Beta, goes out after night,

And steals for his frat one fat pig.

He is caught, he is tried, and he is sentenced, he pays,

But not as compared to myself.

Again, the poem referenced an actual incident when 18 women obtained permission to go to a movie on March 7, 1919. Instead, they attended an unchaperoned public dance in downtown Ames. As punishment, they lost all social privileges for the first six weeks of the spring quarter. ${ }^{32}$

For the women of Theta Sigma Phi, silly poems, cartoons, blurbs, and stories were not only ideological critiques but also pointed criticisms of the realities they regularly encountered. They were well aware of sexism on campus and in the professional

31. Jordan, "1919," 4; Untitled poems and untitled cartoons, "At the Beta House," and "Did it Ever Happen to You?" Emerald Goose, 3/19/1919, 11-13, 15, 22, 25, 27,30 . The incident of men climbing into a women's dormitory is verified in "Interview with Miss Fredrica Shattuck, Retired Professor of Speech, January 15, 1959," Iowa State University Archives, Parks Library, Iowa State University, Ames, 6-7.

32. “The Double Standard," Emerald Goose, 3/19/1919, 13. 


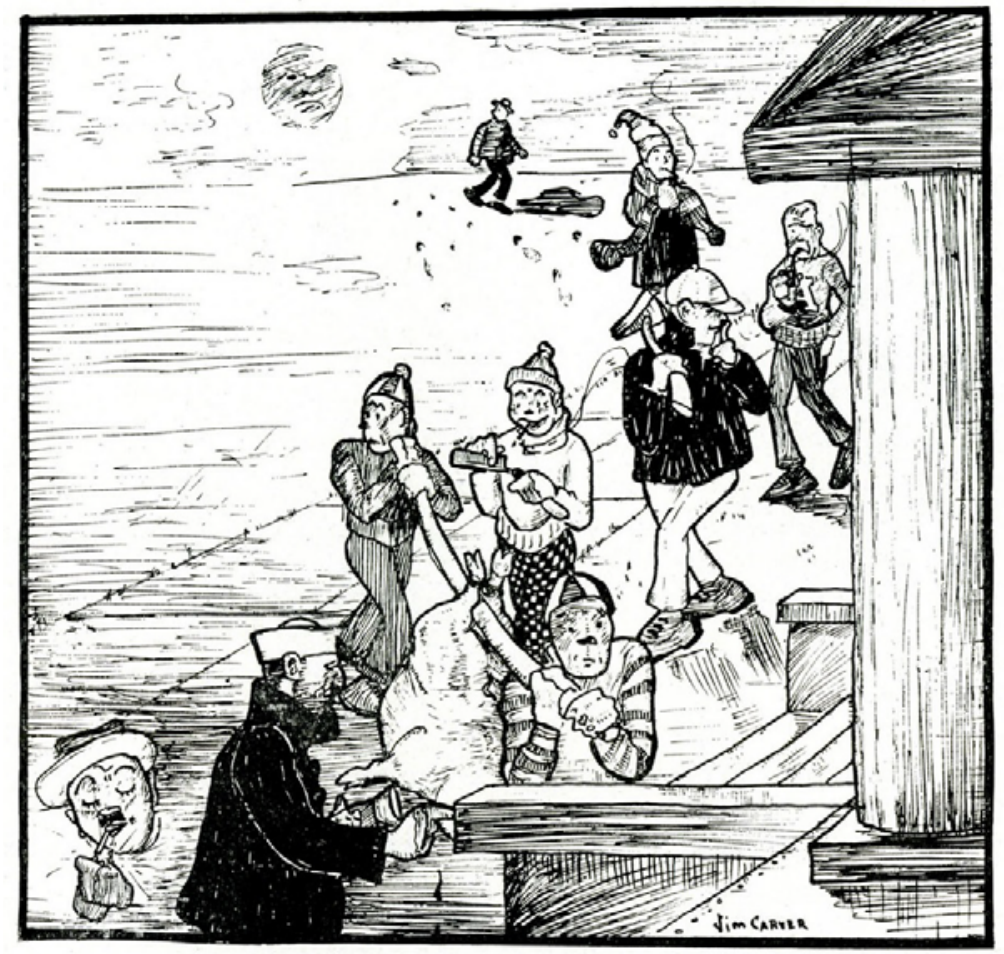

Hark, hark, the dogs do bark,

The Betas are coming to town,

So lock up your hogs, unchain your dogs

And nail your front porch down.

From The Emerald Goose, 3/19/1919.

world that awaited them. Amid the blurbs and poems about campus life, the 1919 issue featured a poem reminding women never to "ask for quarter as a woman," and to "play the game just as a man can play." The poem warned women that they would encounter "crime and dirt," but concluded,

If you can do a man's work with men

And never lose your womanhood,

Why you can be a journalist, kid,

Here's to you, girl - make good!"33

33. "An 'If' for the Theta Sigs," Emerald Goose, 3/19/1919, 8. 
THE SECOND ISSUE of the Emerald Goose appeared in March 1919. It was released amid growing student unrest that was further captured in the returning issue of the Green Gander, published one month later in April 1919. Yet rather than expressing camaraderie with the staff of the Emerald Goose, the men of Sigma Delta Chi were unequivocally antagonistic. An editorial in the Green Gander praised the men who had served in the military and boldly proclaimed a new era in journalism. Men who had seen war and traveled the world brought a "youthful vigor" to the profession. Another editorial expressed relief at the reappearance of the Green Gander and asked whether the Emerald Goose had sufficiently filled its place in wartime. The answer: "Heaven help us, NO!" The editors could "scarce wait until the simple reading folk have recovered from the startling revelations that dear goose made." The same issue featured a poem dedicated to the staff of the Emerald Goose.

You can talk about the women's rights,

And the talent that they show,

But the way they butchered that poor book

To me was an awful blow.

Their jokes were old, their take-offs crude,

And it meant naught to me.

I rise right now to let you know

It was not worth twenty C. ${ }^{34}$

Even if the criticisms were intended humorously, they were overtly hostile and dismissive of the women's work, going well beyond simple chiding or rivalry.

The women of Theta Sigma Phi did not even have an opportunity to respond before the Green Gander released a special homecoming issue in November 1919. Again, an article made light of women's demands for equality by stating that they should be denied special considerations and polite customs. The article declared, "They have howled and pleaded, argued and bleeded, raved and lobbied, for many many generations of hair restorer begging, nay beseeching and screeching for EQUAL RIGHTS. And now they have them." The article then went on to

34. “Again," Green Gander, 4/17/1919, 18; “The Emerald Goose," ibid., 9. 
state that because women had achieved their goal, men should no longer give right of way to women on sidewalks, give up a seat on a streetcar, open doors, "carry bundles, fire the furnace, earn the living, and do the thousand and one other things which we mere sterner sex have to do at present. Bet they even regret the fact that they can't shave." 35

By March 1920, when the next issue of the Emerald Goose was published, the campus climate had changed considerably. In addition to incidents of hazing and general unrest during the spring of 1919, students began to intentionally organize protests. One major point of contention was a rule limiting student dances on campus and in fraternity houses to Saturday nights, with a strict closing time of 11 p.m. For months, the Cardinal Guild and the Women's Guild (the auxiliary to the student government) had petitioned administrators to allow dances on Fridays and Saturdays until midnight. Hoping to provoke a response, at several dances on April 5, 1919, students distributed fliers that read, “Dance until twelve o' clock. Stick by the Ship. Don't get cold feet. United we stand, divided we fall." Even when authorities extinguished the lights, many continued to dance well into the night. ${ }^{36}$

President Raymond Pearson eventually compromised and allowed dancing on Friday nights, but he initially responded with a heavier hand, demanding a "manly" apology from the Cardinal Guild and expressing stern disappointment in "good students" who willingly broke rules. The Cardinal Guild furnished the apology, and Pearson demonstrated some flexibility as he engaged faculty and students in assessing social regulations. Many faculty asserted that there were too many rules and students should be allowed greater freedom, but administrators were reluctant to institute more liberal policies. In June 1919 Pearson and the Board of Deans, under pressure from an outraged Alumni Association, decided that campus humor magazines "should be properly censored." The board's minutes do not specify content that provoked this response, and they identified Sigma Delta Chi as the primary culprit, but their use of the plural in reference to "organizations" and "magazines" implies a reference

35. Green Gander, 11/15/1919, 19.

36. Jordan, “1919,” 5-6. 
to the controversial 1919 issue of the Emerald Goose. The deans concluded that should the students refuse to cooperate, the sponsoring organizations would be "discontinued." 37

Tensions boiled over in the fall of 1919. A group of vocal students demanded that classes be canceled on November 11, 1919, in honor of Armistice Day. Administrators planned commemoration ceremonies but insisted that classes be held until 10:30 a.m. As rumors of unrest spread, the Board of Deans preemptively agreed to punish any protesters, especially the ringleaders. In the end, they suspended one student indefinitely, placed 21 on probation, and fired two sympathetic faculty members. Their actions had the desired effect, as no further cases of student misconduct appear in the minutes of the Board of Deans for the remainder of the 1919-20 academic year. It is within this context that the women of Theta Sigma Phi began work on the 1920 issue of the Emerald Goose. All but two of the women who had worked on the 1919 issue had either graduated or left school, and with the administration tightening the reins on student behavior, the new staff may have been reluctant to push the boundaries of acceptable feminine behavior. ${ }^{38}$

Despite the threat of censorship, the Emerald Goose's writers continued to express their sexuality. A 1920 poll from the women of East Hall, a women's dormitory, asked who had or had not been kissed. With the caveat that the statistics would not "spoil" anyone's "chance for dates," the poll listed the names of the women in three categories: "I Have," "I Have Not," and "We Would If They Would." Of the 40 women polled, 28 claimed to have been kissed, 6 had not, and 6 wished for the opportunity. One woman in the "I Have" category added, "Hell, yes," next to her name, while another added, "Proud of it." In 1921 the women dedicated that year's issue to the "art of campustry," or the practice of bending the rules and flirting with men. They even attempted to show the extent of their liberation by publishing women's rules from the late nineteenth century. ${ }^{39}$

37. Ibid., 6-7; Minutes, Fifty First Meeting of the Board of Deans, 6/10/1919, Iowa State University Archives, Parks Library, Iowa State University, Ames.

38. Ibid.

39. “I Ain't Never Been Kissed,” Emerald Goose, March 1920, 15. 
Still, the 1920 and 1921 issues of the Emerald Goose took on a more conservative tone, perhaps because of the threat of censorship. Compared to the 1918 and 1919 issues, those in 1920 and 1921 featured more jokes, poems, and blurbs framing women's sexuality within the context of marriage. By focusing on marriage, the women reinforced ISC's rules that required women's lives to be strictly monitored and controlled. For example, a short poem that encouraged following college rules stated,

'Tis wrong for a maid to be

Abroad at night alone!

A chaperone she needs 'till she

Can call some chap-her-own.

A 1920 poll of fraternities sought the "most marriageable men on the market." One man from Sigma Phi Epsilon nominated a fraternity brother based on his willingness to "eat anything, thereby eliminating all waste as well as meal-planning. He is an inveterate sleeper, so his wife need not worry about his staying out all night." 40

The women of Theta Sigma Phi occasionally included an item in defiance of the administration's threat of censorship. In the 1921 issue a cartoon of an old, dour woman was accompanied by a poem that read,

Mary, Mary, Quite Contrary,

How did your Goose come out?

With censors three, so good are we

Just send it home without a doubt. ${ }^{41}$

They also continued to make clear calls for equal opportunity through discussions of suffrage and gainful employment. In 1920 an article titled "How Will You Vote?" encouraged college women to become informed and active voters. Their immediate goal was not to better society, but rather to prove their capabilities to the men who opposed woman suffrage. The writer of the article pointed out that women should not feel bad if men

40. Untitled poem and "The Most Marriageable Men on the Market," Emerald Goose, March 1920, 6. The editors of the Green Gander seem to have been less constrained by the threat of censorship than those of the Emerald Goose.

41. Untitled poem, Emerald Goose, May 1921, 31. 
laughed at their desire to vote because "eight men out of every ten, right here at ISC, do not know the meaning of some of the most common terms used in voting." 42

In 1921 the Emerald Goose advertised a new journal, the Women's National Journalistic Register, produced by the national Theta Sigma Phi organization. One purpose of the journal was to announce employment opportunities and "lessen the periods of unemployment or hack work, the long struggle, almost inevitable, for girls of literary aspiration." The editors of the Emerald Goose donated a "large share" of the proceeds from their sales to the Women's National Journalistic Register and planned to do so until the journal became self-supporting. The article concluded, "Thus we feel that the Iowa State Chapter of Theta Sigma Phi is doing its 'bit' for women in journalism." 43

THE EXPERIENCE of establishing Theta Sigma Phi and publishing the Emerald Goose provided the structure and organization women needed to promote themselves as journalists on campus and after graduation. In 1919 chapter membership grew to 17 women, and by that summer five alumnae of Omicron chapter working in Des Moines teamed up with Merze Marvin to found Theta Sigma Phi's second professional chapter in the nation. Having experienced success at the collegiate level, they hoped to carry the advantages of networking and professional development into the workplace. Following her marriage to attorney Vernon Seeberger in 1919, Marvin embarked on a successful freelancing career composing features for Des Moines newspapers and national magazines, earning enough to hire a housekeeper so that she could write. Even when pregnant with her first child, she enthusiastically corresponded with national president Marion Lewis about the creation of the Women's National Journalistic Register because male "editors aren't going to come to us." 44

Unfortunately, four years of success did not translate into longevity for the Emerald Goose. In 1920 Theta Sigma Phi lost one

42. "How Will You Vote?" Emerald Goose, March 1920, 10.

43. "Women's Journalistic Register," Emerald Goose, May 1921, 8.

44. Theta Sigma Phi Alumna Chapter, Des Moines, to Marion Lewis, 8/4/1919, and Merze Seeberger to Marion Lewis, 8/2/1919 and 8/30/1919, WIC Records. 
of its most critical advocates when Harry O'Brien left ISC to become associate editor of the Country Gentleman in Philadelphia. His efforts to bring more women into the journalism program convinced ISC administrators to support the introduction of the Iowa Homemaker in 1921 as a publication on par with the Iowa Agriculturalist and the Iowa Engineer. The Iowa Homemaker provided opportunities for writing, editing, and advertising, but it also reinforced gendered divisions within journalism. Because women had their own outlet, men were not obliged to provide greater access to existing campus publications, and women were further discouraged from writing for general audiences and using humor to critique sexism. ${ }^{45}$

In 1922 the Green Gander announced its "engagement," or "more lamentably our marriage," to the Emerald Goose as the former allowed women on its staff and the latter ceased production. The exact reasons for this compromise are unclear, but the result was a silencing of women's humor. Theta Sigma Phi and Sigma Delta Chi claimed equal ownership of the magazine, but an editorial in the February 1922 issue of the Green Gander made it clear that "Mrs. Gander may have a different version, but in this family the male member will wear the trousers." Only five women worked on the magazine that year. One served as associate editor and four served as "Gander Sleuths." By the May 1922 issue, the number of women increased to eight, with two associate editors, one art contributor, one editorial contributor, and four Gander Sleuths. By the October 1922 issue, however, the number regressed to five: two associate editors, two art contributors, and one Gander Sleuth. The only time between 1922 and the magazine's demise in 1960 that women made up more than half of the Green Gander staff was during World War II. The presence of women on the staff also failed to transform the content of the magazine; it remained largely antagonistic toward female students. For example, the February 1922 issue of the Green Gander included "Advice to College Co-Eds," such as "Do not drink from a drinking fountain. The dew drops on your lips incite the men to wild thoughts." As the list went on, it served as a reminder to women that, as a small minority on campus, their bodies and daily be-

45. “Class Personals,” Ohio State University Monthly 11 (July 1920), 59. 
havior were under scrutiny not only by college administrators but also by male students. ${ }^{46}$

ALTHOUGH the Emerald Goose lasted just four years, it nonetheless represented a determined effort on the part of women at ISC to promote women in journalism on campus and within the profession. The magazine could easily be considered a temporary wartime measure, yet the women of Theta Sigma Phi clearly wished to create a lasting organization to further their own professional goals. In their 1925 annual report to the national chapter, members of Omicron chapter continued to reflect the founders' goals. They reported that ISC offered a new journalism major, and they hoped to attract more female students to the field by asking the department to hire female faculty. ${ }^{47}$

The students also carried experiences afforded by the Emerald Goose and Theta Sigma Phi into professional careers. In a 1942 alumnae survey, Katherine Proper ('26) listed her occupation as "homemaker-freelance home economics writer." Following graduation, she balanced childrearing with publishing articles in Country Gentleman, Better Homes and Gardens, Successful Farming, and Better Homes and Gardens. Marjorie Griffin ('37) went on to become assistant editor at Successful Farming for two years, and in 1939 she began writing a daily food column for the Detroit Times under the name Prudence Penny. Virginia Garberson Rich ('34) wrote a food column for the Chicago Tribune. ${ }^{48}$

Others pursued careers as home economics teachers and home demonstrations agents and in a variety of other professional fields. Founder Phoebe Mentzer ('22) earned a master's degree in chemistry from ISC in 1925, married in 1930, and then taught chemistry at the University of Washington in Seattle. In 1970 Gladys Gallup Wilson ('18) specified her occupation as "housewife," yet she had earned graduate degrees in education from George Washington University in Washington, D.C., and pursued a successful career as an extension specialist with the

46. "United" and "Advice to College Co-Eds," Green Gander, February 1922, 4, 7; Bomb (1918), 170-77; Bomb (1919), 245.

47. Annual Report of Omicron Chapter, 1925, in WIC Records.

48. Alumnae survey by the members of Omicron Chapter, 1942, WIC Records. 
U.S. Department of Agriculture (USDA). At the time of her retirement in 1960, Wilson was working as the director of a division of extension research and training for the USDA. Similarly, Virginia Lowe ('19) married in 1920, and in 1964 she listed her occupation as "housewife." Nonetheless, she had taught at Peru State College in Peru, Nebraska, and had done "journalism work" for the Omaha Daily News. On a 1958 alumnae information form, the assistant editor of the first Emerald Goose, Bess Bartley ('18), indicated that she had married twice and worked on several newspapers before taking ownership of a concrete pipe factory in Atlanta, Georgia. Although none of these women directly pursued careers in journalism, their activities indicated a desire to apply their degrees to professional occupations. ${ }^{49}$

The members of the Omicron Chapter of Theta Sigma Phi began organizing in 1917 with the intention of enhancing women's access to journalism programs at Iowa State College. The urgency of World War I created an opening for them to publish a unique humor magazine with a distinctive female voice, but the conflict itself and the ensuing rhetoric of women's patriotic duty did not necessarily fuel their determination to make their way in a maledominated field. Nor did it alter deeply engrained sexist attitudes on the part of administrators or male students. Only in a moment of crisis, when administrators were preoccupied with containing the Spanish influenza, could the women push the boundaries of supposedly appropriate behavior. In their petition to the national chapter of Theta Sigma Phi, the women of ISC recognized that they faced several obstacles, but they hoped to improve women's participation on student publications and make the journalism program more inclusive. The women claimed, "As individuals we have tried separately to accomplish some of these things. We believe that organized, with a chapter of Theta Sigma Phi, we could work in harmony to much better ends." 50

49. Phoebe Mentzer Lindquist, obituary, 5/10/1965, Alumni Records, RS 21/7/1, Special Collections, Iowa State University Library, Ames; Gladys Gallup Wilson to Iowa State University Alumni Office, 1970, ibid.; "Mrs. Wilson Was Extension Director," obituary, 1983, ibid.; Virginia Lowe Good to Iowa State University Alumni Office, 5/21/1964, ibid.; Bess Bartley Mulholland to Iowa State College Alumni Office, 3/19/1958, ibid.

50. "Petition to Theta Sigma Phi," Theta Sigma Phi Records. 
The short-lived career of the Emerald Goose reveals the delicate balancing act women on college campuses performed to justify their public voices and participation in publishing. An editorial in the first issue of the Emerald Goose hints that its staff understood women's public roles to be problematic. "Tho the Emerald Goose aims to tell the truth," the writer stated, "we do not vouchsafe that she states the whole truth and nothing but the truth. She has tried to be kind, tho critical, sensible, tho silly, and humble tho humorous." In some ways, this statement summarized the women's attitudes toward a system that excluded them from curricular and extracurricular journalism and that required them to adapt their language so as not to be too outspoken. Perhaps what they did not realize is that nearly a century later, we would continue to take their words at face value and believe that these women harbored no higher aspirations. It is only by delving into the broader context and reading their organizational records that we learn how they faced significant resistance from male editors, colleagues, and students. They understood very well the limitations placed on them. Undaunted, they systematically built local, state, and national networks to overcome those barriers and define themselves as professionals. ${ }^{51}$

51. "Nothing But the Truth," Emerald Goose, 4/12/1918, 8. 